\title{
Kinga Grablis
}

Uniwersytet Mikołaja Kopernika, Toruń

kinga-grablis@wp.pl

ORCID: https://orcid.org/0000-0001-9886-4680

\section{Więzi rodzinne a problematyka dóbr osobistych}

http://dx.doi.org/10.12775/SIT.2021.002

Więzi rodzinne w kontekście dóbr osobistych to zagadnienie budzące zainteresowanie zarówno doktryny, jak i orzecznictwa. Pytanie o ich charakter staje się aktualne w szczególności w momencie, kiedy pośrednio pokrzywdzeni bezprawnym naruszeniem dobra osobistego innej osoby (w tym przypadku członka ich rodziny), wnosząc o zadośćuczynienie na podstawie art. 448 Kodeksu cywilnego ${ }^{1}$, odwołują się do ich własnego dobra osobistego. Kompensacja krzywdy spowodowanej naruszeniem więzi rodzinnej to problem tak doniosły, że na przestrzeni lat wielokrotnie stawał się przedmiotem rozważań Sądu Najwyższego, w tym mających rangę uchwał składu siedmiu sędziów. Do 2019 r. orzecznictwo Sądu Najwyższego było w tym zakresie jednolite. Sąd konsekwentnie przyznawał więziom rodzinnym status dobra osobistego. Jednocześnie oznaczało to, że powołując się na naruszenie więzi rodzinnej, możliwe jest uzyskanie $z$ tego tytułu zadośćuczynienia na podstawie art. 448 k.c. W trzech jednobrzmiących uchwałach Sąd Najwyższy - Izba Cywilna w skła-

${ }^{1}$ Ustawa z 23 kwietnia 1964 r. - Kodeks cywilny (t.j. Dz.U. z 2020 r. poz. 1740 ze zm.), dalej: k.c. 
dzie siedmiu sędziów orzekł: „Sąd może przyznać zadośćuczynienie za krzywdę osobom najbliższym poszkodowanego, który na skutek czynu niedozwolonego doznał ciężkiego i trwałego uszczerbku na zdrowiu" ${ }^{2}$. W uchwale $z$ dnia 22 października 2019 r., I NSNZP 2/19 Sąd Najwyższy - Izba Kontroli Nadzwyczajnej i Spraw Publicznych w składzie siedmiu sędziów ${ }^{3}$ zdecydowanie odmówił jednak więziom rodzinnym statusu dobra osobistego, stanowiąc, że: „Osobie bliskiej poszkodowanego, który na skutek czynu niedozwolonego doznał ciężkiego i trwałego rozstroju zdrowia, nie przysługuje zadośćuczynienie pieniężne na podstawie art. 448 k.c.”. W efekcie w obrocie prawnym funkcjonują sprzeczne ze sobą uchwały Sądu Najwyższego odnoszące się do tego samego zagadnienia. Żadna z nich nie ma rangi zasady prawnej. O jej wydanie wniósł Rzecznik Praw Pacjenta, zwracając uwagę na negatywne konsekwencje, jakie rodzi taki stan rzeczy ${ }^{4}$. Bez wątpienia bowiem nieustalony status więzi rodzinnych jako dobra osobistego stanowi podstawę do kwestionowania zasadności roszczenia o zadośćuczynienie $z$ tytułu ich naruszenia na podstawie art. 448 k.c.

\section{Pojęcie dobra osobistego}

W doktrynie sformułowano wiele propozycji określenia instytucji dobra osobistego. Dobrom tym brak jednolitej struktury i treści, zatem bada się wspólne dla nich cechy charakterystyczne ${ }^{5}$. Analizując pojęcie dobra osobistego, należy zwrócić uwagę na dwie

${ }^{2}$ Uchwały składu siedmiu sędziów Sądu Najwyższego z 27 marca 2018 r. o sygnaturach: III CZP 60/17, Legalis nr 1781927; III CZP 69/17, Legalis nr 1740654; III CZP 36/17, Legalis nr 1740652.

${ }^{3}$ Uchwała składu siedmiu sędziów Sądu Najwyższego z 22 października 2019 roku, I NSNZP 2/19, Legalis nr 2236263.

${ }^{4}$ Wniosek o rozstrzygnięcie zagadnienia prawnego z 30 października 2019 r. Rzecznik Praw Pacjenta podniósł kwestię niepewności osób uprawnionych co do przysługującego im roszczenia oraz zagrożenie utrwalenia się rozbieżności w orzecznictwie Sądu Najwyższego i sądów powszechnych.

${ }^{5}$ T. Grzeszak, Dobro osobiste jako dobro zindywidualizowane, „Przegląd Sądowy" 2018, nr 4, s. 7. Tekst został pierwotnie opublikowany w: Experientia 
koncepcje: subiektywną oraz obecnie dominującą - obiektywną. Pierwszą z nich rozwijał Stefan Grzybowski. Zwrócił on uwagę, że „wspólną, charakterystyczną cechą wszelkich dóbr osobistych są niemajątkowe, indywidualne wartości świata uczuć, stanu życia psychicznego człowieka. [...] Przedmiotem ochrony jest uczucie ludzkie, niezmącony stan życia psychicznego"6. Podniósł zarazem, że uczucie przywiązania do bliskich może korzystać $z$ ochrony tylko na mocy szczególnych przepisów ustawowych ${ }^{7}$. Odmienne jest stanowisko przedstawicieli koncepcji obiektywnej (m.in. Adama Szpunara, Andrzeja Ciska, Janiny Panowicz-Lipskiej), którzy skupiają się na konieczności obiektywizacji dóbr za pomocą odwołania się do przyjętych w społeczeństwie ocen. Bierze się pod uwagę stan psychiczny powoda, jednak nie jest on czynnikiem decydującym o tym, czy naruszono jego dobro osobiste. Obiektywizacja polega bowiem na odwołaniu do uczuć „rozsądnego, uczciwego” człowieka ${ }^{8}$. To, czy konkretna wartość jest dobrem osobistym i czy doszło do jej naruszenia, zależy od opinii społeczeństwa. Cechy dobra osobistego syntetycznie wskazuje definicja sformułowana przez Sąd Najwyższy w wyroku z 6 maja 2010 r.: „Dobra osobiste ujmowane są w kategoriach obiektywnych, jako wartości o charakterze niemajątkowym, ściśle związane $z$ człowiekiem, decydujące o jego bycie, pozycji w społeczeństwie, będące wyrazem odrębności fizycznej i psychicznej oraz możliwości twórczych, powszechnie uznane w społeczeństwie i akceptowane przez system prawny"9. Sąd Najwyższy zwrócił przy tym uwagę na otwartość katalogu dóbr osobistych, co oznacza możliwość wyinterpretowania dobra osobistego $\mathrm{z}$ art. 23 k.c., jeżeli przemawiają za tym zachodzące $\mathrm{w}$ społeczeństwie zmiany.

docet. Księga jubileuszowa ofiarowana Pani Profesor Elżbiecie Traple, red. P. Kostański, P. Podrecki, T. Targosz, Warszawa 2017, s. 876-909.

${ }^{6}$ S. Grzybowski (red.), System prawa cywilnego, t. 1. Część ogólna, Wrocław-Warszawa-Kraków-Gdańsk-Łódź 1985, s. 297.

7 Ibidem, s. 103.

8 P. Sobolewski, w: Kodeks cywilny. Komentarz, red. K. Osajda, Warszawa 2017, s. 126.

${ }^{9}$ Wyrok Sądu Najwyższego - Izba Cywilna z dnia 6 maja 2011 r., II CSK 640/09, Legalis nr 248327. 


\section{Pojęcie więzi rodzinnych}

Mimo że więzi rodzinne były przedmiotem wielu wypowiedzi Sądu Najwyższego, zakres tego pojęcia jest niejasny. Problem sprawia już samo jego nazwanie. Sąd Najwyższy w swoich orzeczeniach używał m.in. określeń: „więź rodzinna” ${ }^{10}$, „więź rodzinna, której zerwanie powoduje ból, cierpienie i rodzi poczucie krzywdy" ${ }^{11}$ czy „silna więź emocjonalna, szczególnie bliska w relacjach rodzinnych" ${ }^{12}$. Nie każde więzi rodzinne mogą być objęte ochroną przewidzianą dla dóbr osobistych. W wyroku z dnia 9 sierpnia 2016 r. ${ }^{13}$ Sąd Najwyższy zaznaczył, że więzi rodzinne, by móc zostać uznane za dobro osobiste, „muszą przybierać postać rzeczywistych, silnych, trwałych więzi emocjonalnych, których istnienie przejawia się na zewnątrz w taki sposób, że możliwa jest obiektywna weryfikacja ich istnienia i nie mogą być utożsamiane jedynie $z$ uczuciem przywiązania do innej osoby", nie wskazał jednak na cechę, która pozwoliłaby odróżniać je od przywiązania. W późniejszym orzecznictwie Sąd Najwyższy odwołał się do kryterium „formalnego stosunku prawnorodzinnego” oraz „stosunku niesformalizowanego pod względem prawnym, wymagającym udowodnienia przez uprawnionego" 14 . Może jednak rodzić wątpliwości to, czy sam fakt pozostawania w stosunku prawnorodzinnym, np. małżeństwie, może świadczyć o istnieniu więzi bliskości, a co za tym idzie - więzi rodzinnej. Ponadto, jeżeli kluczowym składnikiem tego dobra osobistego są także więzi emocjonalne ${ }^{15}$, to należy zwrócić uwagę na problem ich

${ }^{10}$ Uchwała Sądu Najwyższego - Izba Cywilna z dnia 22 października 2010 r., III CZP 76/10, Legalis nr 254081.

${ }^{11}$ Uchwała Sądu Najwyższego - Izba Cywilna z dnia 13 lipca 2011 r., III CZP 32/11, Legalis nr 344782 .

${ }^{12}$ Uchwała Sądu Najwyższego - Izba Cywilna z dnia 12 grudnia 2013 r., III CZP 74/13, Legalis nr 742161.

${ }^{13}$ Wyrok Sądu Najwyższego - Izba Cywilna z dnia 9 sierpnia 2016 r., II CSK 719/15, Legalis nr 1507564.

${ }^{14}$ Uchwała składu siedmiu sędziów Sądu Najwyższego z dnia 27 marca 2018 r., III CZP 36/17, Legalis nr 1740652.

15 Zob. wyrok Sądu Najwyższego - Izba Cywilna z dnia 6 lutego 2015 r., II CSK 334/14, Legalis nr 1187396. 
trwałości. Jak podkreślił Sąd Apelacyjny w Katowicach w wyroku z dnia 15 maja 2015 r.: „uczucia między ludźmi, nawet najbliższymi krewnymi, są wypadkową wielu czynników i zależą, między innymi, od ich stosunków z pozostałymi członkami rodziny, od fizycznej bliskości lub fizycznego dystansu, od cech ich charakteru i wielu innych" ${ }^{16}$. Przedstawiciele nauki prawa cywilnego zwracają uwagę, że to faktyczne związki pomiędzy bliskimi powinny decydować o istnieniu więzi rodzinnej ${ }^{17}$. Bez wątpienia nie można przyjąć a priori, że członków rodziny wiążą silne, bliskie stosunki. W doktrynie zwraca się uwagę, że jedynie takie więzy rodzinne, które łączą najbliższych członków rodziny, mogą uzyskać ochronę na gruncie art. 24 k.c ${ }^{18}$. Zatem tylko istnienie bardzo silnej więzi, takiej jak np. między rodzicami a dziećmi, może stanowić dobro osobiste ${ }^{19}$.

Wobec niedookreślonego zakresu pojęcia „więzi rodzinne” były przywoływane w odniesieniu do różnych stanów faktycznych ${ }^{20}$. Traktując je jako dobro osobiste, na gruncie art. 448 k.c. zaczęto rozważać związane $z$ nimi bezprawne ingerencje, skutkujące ich naruszeniem, ale nie zerwaniem (takiego stanu, wobec śmierci członka rodziny, wymaga art. $446 \S 4$ k.c.). Sąd Najwyższy, odnosząc się do

16 Wyrok Sądu Apelacyjnego w Katowicach z dnia 15 maja 2015 r., I ACa 131/15, Legalis nr 1263391.

17 M. Wałachowska, Cywilne prawo - zobowiazania - czyn niedozwolony naruszenie dóbr osobistych członków rodziny $w$ związku ze spowodowaniem śmierci osoby bliskiej. Glosa do wyroku SN z dnia 14 stycznia 2010 r., IV CSK 307/09, „Orzecznictwo Sądów Polskich” 2011, nr 2, s. 15.

18 B. Lackoroński, Cywilne prawo - zobowiązania - dobra osobiste - czyn niedozwolony - zadośćuczynienie pieniężne za doznaną krzywdę $w$ związku ze śmiercią najbliższego członka rodziny na skutek deliktu, który miał miejsce przed dniem 3 sierpnia 2008 r. Glosa do uchwały SN z dnia 22 października 2010 r., III CZP 76/10, „Orzecznictwo Sądów Polskich” 2011, nr 9, s. 96.

19 M. Wałachowska, Cywilne prawo - zobowiazania - dobra osobiste - czyn niedozwolony - zadośćuczynienie pieniężne za doznaną krzywdę $w$ związku ze śmiercią najbliższego członka rodziny na skutek deliktu, który miał miejsce przed dniem 3 sierpnia 2008 r. Glosa do uchwały SN z dnia 22 października 2010 r., III CZP 76/10, OSP 2011, nr 9, s. 669.

20 Wskazywano, że bezprawne naruszenie dobra osobistego w postaci więzi rodzinnych mogą stanowić m.in.: zamiana dzieci w szpitalu (zob. wyrok Sądu Najwyższego - Izba Cywilna z dnia 18 czerwca 2014 r., V CSK 463/13, Lega- 
więzi rodzinnych rozumianych jako dobro osobiste, opisywał różne związane $z$ tym dobrem prawa, m.in. do życia w rodzinie ${ }^{21}$, do życia rodzinnego i rodzicielstwa, do dorastania w biologicznej rodzinie i do wychowywania biologicznych dzieci ${ }^{22}$. W orzecznictwie sądów powszechnych wskazuje się także m.in. na prawo do: pełnej najbliższej rodziny, spokojnego rozwoju w okresie dzieciństwa i młodości oraz zaspokajania potrzeb emocjonalnych i pożycia fizycznego ${ }^{23}$.

Warto zwrócić szczególną uwagę na „zrównanie” stanu zerwania więzi rodzinnej, do jakiej dochodzi z chwilą śmierci bliskiej osoby, z niemożnością jej nawiązania czy jej „niepełnością” ${ }^{44} \mathrm{w}$ sytuacji, gdy osoba ta nadal żyje. Sąd Najwyższy zwrócił uwagę, że „Skoro w utrwalonym i jednolitym orzecznictwie Sądu Najwyższego uznaje się, że zadośćuczynienie na podstawie art. 448 k.c. przysługuje w razie śmierci bliskiego, to niezasadne jest odmawianie go, gdy to samo dobro ucierpiało ciężko, chociaż w inny sposób. W razie pozostawania osoby najbliższej w nieodwracalnym stanie śpiączki lub trwałego stanu wegetatywnego dochodzi do podobnych skutków jak w przypadku śmierci, a sytuacja taka jest porównywalna z zerwaniem więzi z osobą bliską, która straciła życie"25. Do naruszenia więzi rodzinnej może zatem dojść pomimo że członek rodziny żyje.

W stanach faktycznych będących podstawą takich spraw istotą jest, że na skutek czynu bezprawnego bliski doznał ciężkiego

lis $n r$ 1067202), utrudnianie utrzymywania kontaktu $z$ wnuczką (zob. wyrok Sądu Apelacyjnego w Katowicach z dnia 29 stycznia 2013 r., I ACa 906/12, Legalis nr 732676).

${ }^{21}$ Wyrok Sądu Najwyższego - Izba Cywilna z dnia12 września 2013 r., IV CSK 87/13, Legalis nr 728663.

${ }^{22}$ Wyrok Sądu Najwyższego - Izba Cywilna z dnia 18 czerwca 2014 r., V CSK 463/13, Legalis nr 1067202.

${ }^{23}$ Wyrok Sądu Apelacyjnego w Łodzi z dnia 27 lutego 2013 r., I ACa 1076/12, Legalis nr 1024542.

${ }^{24}$ Uchwała składu siedmiu sędziów Sądu Najwyższego z dnia 27 marca 2018 r., III CZP 60/17 - „Problemu nie można też postrzegać w kategoriach istnienia więzi lepszej lub gorszej, nie chodzi bowiem o wartościowanie więzi pomiędzy bliskimi, lecz o istnienie lub nieistnienie wszystkich czynników, które tę więź tworzą".

${ }^{25}$ Ibidem. 
uszczerbku na zdrowiu, co uniemożliwia jego funkcjonowanie w rodzinie. To z kolei jest źródłem cierpienia psychicznego jej członków. W doktrynie krytycznie ocenia się takie rozwiązanie, wskazując na konieczność uważnego rozdzielania problematyki dóbr osobistych od spokoju psychicznego czy też ogólnego dobrostanu człowieka ${ }^{26}$. Sam fakt wystąpienia u powoda cierpienia psychicznego czy dyskomfortu nie oznacza bowiem, że naruszono jego dobro osobiste.

Więź rodzinna, opierająca się na szczególnym związku, na silnej więzi emocjonalnej, ma bez wątpienia relacyjny charakter. $Z$ samej specyfiki więzi rodzinnej wynika, że dla jej zaistnienia konieczne są interakcje między jednym członkiem rodziny a innym lub innymi. Nie jest ona zatem ściśle związana $z$ jednym człowiekiem i zależy od wielu czynników. Cała gama ludzkich emocji towarzyszących codziennemu życiu i wspólnie przeżywanych doświadczeń rzutuje na relacje między ludźmi, a te $z$ kolei przekładają się na intensywność więzi emocjonalnych i bliskości. Mając to na uwadze, nie sposób uznać więzi rodzinnych za część świata wyłącznie jednej osoby. Chociaż niewątpliwie oddziałują one na stan psychiczny jednostki, to zachodzą w świecie zewnętrznym - w sferze między nią a inną osobą. To $z$ kolei określa ich interpersonalny charakter, który przeczy „zindywidualizowanej” naturze dóbr osobistych. W tezie uchwały z dnia 19 listopada 2010 r. Sąd Najwyższy przyjął, że „dobrem osobistym jest wartość immanentnie złączona $z$ istotą człowieczeństwa oraz naturą człowieka, niezależna od jego woli, stała, dająca się skonkretyzować i zobiektywizować" ${ }^{27}$. Fakt, że więzi rodzinne są kształtowane nie tylko przez jedną osobę, a zatem nie zależą wyłącznie od niej, budzi wątpliwości co do tego, czy odpowiadają one przyjętemu przez Sąd Najwyższy sposobowi pojmowania dóbr osobistych. Przede wszystkim jednostka ma wpływ na intensywność, charakter, a nawet samo istnienie bądź nieistnienie więzi łączących ją z innym członkiem rodziny. Trudno zatem

${ }^{26}$ T. Grzeszak, op.cit., s. 19. Autorka wskazuje na tworzący się w orzecznictwie nurt obejmowania ochroną nowych dóbr w celu uzasadnienia zadośćuczynienia za cierpienie związane $z$ naruszeniem chronionych przez nie wartości.

${ }^{27}$ Uchwała Sądu Najwyższego - Izba Cywilna z dnia 19 listopada 2010 r., III CZP 79/10, Legalis nr 260723. 
uznać, aby były one niezależne od jej woli. Więzi tych nie cechuje też stałość - mogą być wzmacniane lub osłabiane, a nawet $z$ woli ich stron zerwane, np. poprzez rozwód.

\section{Więzi rodzinne jako dobro osobiste}

W doktrynie kontrowersje budzi uznanie więzi rodzinnych za dobro osobiste pomimo ich interpersonalnego charakteru. Paweł Księżak wprost stawia tezę, że „uznawanie więzi (miłości, przyjaźni itd.) za dobro osobiste [...] jest wadliwe konstrukcyjnie - dobro osobiste powinno być osobiste, nie może zaś oznaczać bądź wynikać z relacji $z$ inną osobą" ${ }^{28}$. Leszek Bosek wskazuje $z$ kolei, że brak ich ścisłego związku z wewnętrzną sferą życia człowieka powoduje, że - w odniesieniu do definicji Stefana Grzybowskiego - nie mogą być uznane za wartość świata uczuć, nawet zobiektywizowaną ${ }^{29}$. Teresa Grzeszak kompleksowo ujmuje przesłanki uznania danej wartości za dobro osobiste, wymieniając: ścisły związek danej wartości z osobą uprawnionego (bezpośredni związek wartości z dysponentem dobra), niezależność ich bytu od woli innych osób, charakter zindywidualizowany (nie mogą być to zatem wartości przysługujące wspólnocie czy mające powszechny, abstrakcyjny charakter) oraz poddanie się woli uprawnionego ${ }^{30}$. Problem ten podniósł także sędzia Sądu Najwyższego Kazimierz Zawada, zgłaszając zdanie odrębne do uchwały składu siedmiu sędziów Sądu Najwyższego z dnia 27 marca 2018 r. W jego ocenie relacyjny charakter więzi rodzinnej stoi na przeszkodzie ku temu, by uznać ją za dobro osobiste ${ }^{31}$.

Argumentując przyznanie więzi rodzinnej statusu dobra osobistego, Sąd Najwyższy odwołuje się do konstytucyjnej ochrony

${ }^{28}$ P. Księżak, w: Kodeks cywilny. Część ogólna. Komentarz, red. M. Pyziak-Szafnicka, P. Księżak, Warszawa 2014, s. 312.

${ }^{29}$ L. Bosek, W sprawie kwalifikacji więzi rodzinnej jako dobra osobistego (uwagi krytyczne na tle aktualnego orzecznictwa Sadu Najwyższego), „Forum Prawnicze" 2015, nr 3, s. 10.

30 T. Grzeszak, op.cit., s. 40.

${ }^{31}$ Uchwała Sądu Najwyższego z 19 listopada 2010 r., III CZP 79/10, OSNC 2011, nr 4, poz. 41. 
rodziny. W uzasadnieniu uchwały $z$ dnia 22 października $2010 \mathrm{r}$. Sąd Najwyższy podniósł, że więzi rodzinne, jako „fundament prawidłowego funkcjonowania rodziny", podlegają ochronie prawnej przewidzianej w art. 18 i 71 Konstytucji RP. Niewątpliwie daje to aksjologiczne uzasadnienie dla objęcia więzi rodzinnej specjalną ochroną przewidzianą dla doniosłych społecznie wartości, jakimi są dobra osobiste. W omawianym już wyroku $z$ dnia 9 sierpnia 2016 r. Sąd Najwyższy wskazał, że „ochrona prawna dóbr osobistych powinna być tym szersza, im wyższą wartość w hierarchii dóbr ma określone dobro osobiste. Trudno przyjąć, by ochronie mógł podlegać wizerunek człowieka, jego głos, stan cywilny, prywatność, poczucie przynależności do określonej płci, kult pamięci osoby zmarłej, tradycja rodzinna, nietykalność mieszkania, tajemnica korespondencji, a więź między rodzicami a dzieckiem miałaby być z tej ochrony wyłączona"32.

Zarówno doktryna, jak i orzecznictwo wskazują jednak, że regulacje konstytucyjne nie mogą stanowić samoistnej podstawy żądania ochrony cywilnoprawnej. Rodzinie, małżeństwu i rodzicielstwu przyznano znaczenie prawne i potwierdzono ich wartość społeczną, ale nie oznacza to, że konieczne jest włączenie więzi rodzinnych do katalogu dóbr osobistych. W tezie postanowienia z dnia 21 sierpnia 2020 r. Sąd Najwyższy wskazał, że „nie każda wartość konstytucyjna, w tym $z$ pewnością prawo podstawowe lub wolność podmiotowa, stanowią dobro osobiste. Prawa bowiem i wolności konstytucyjne stanowią konstrukcje normatywne, służące ochronie określonych wartości, które ustrojodawca uznaje lub deklaruje jako podlegające ochronie tak w Konstytucji, jak i w ustawodawstwie zwykłym"33. W uzasadnieniu sąd zwrócił także uwagę, że skonstruowanie katalogu dóbr osobistych i zdefiniowanie ich należy do ustawodawcy; Konstytucja RP nie formułuje zatem wykazu wartości, które podlegają przewidzianej dla nich ochronie.

${ }^{32}$ Wyrok Sądu Najwyższego - Izba Cywilna z 9 sierpnia 2016 r., II CSK 719/15, Legalis nr 1507564.

${ }^{33}$ Postanowienie Sądu Najwyższego - Izba Cywilna z 21 sierpnia 2020 r., V CSK 557/19, Legalis nr 2490668. W tej sprawie sąd analizował prawo do rzetelnego postępowania sądowego. 
W związku z tym fakt, że więzi rodzinne są chronione przez regulację na poziomie konstytucyjnym, nie oznacza, że automatycznie przysługuje im status dobra osobistego.

Argumentując zasadność takiej kwalifikacji więzi rodzinnej, Sąd Najwyższy podniósł także w uchwale $z$ dnia 22 października 2010 r. ${ }^{34}$, że skoro kult pamięci stanowi dobro osobiste, to a fortiori należy przyjąć, że więzi rodzinnej tym bardziej przysługuje taki status, skoro dotyczy ona osób żyjących. Wydaje się jednak, że kult pamięci po zmarłym chroni inne wartości i sfery życia wewnętrznego człowieka niż więzi rodzinne. Kult pamięci zmarłego ma bez wątpienia osobisty charakter ${ }^{35}$. Obejmuje m.in. prawo do pochowania zwłok, wybudowania nagrobka, odwiedzania go i odbywania ceremonii. Jednostka, realizując te prawa, może przeżywać żałobę ${ }^{36}$.

Istotnym aspektem analizy więzi rodzinnej jest kwestia tego, czy poddają się one woli osoby uprawnionej. Chodzi o przysługujące dysponentowi dobra uprawnienie do wyrażania zgody na zachowania innych osób ingerujące $\mathrm{w}$ to dobro. To także roszczenia zakazowe i nakazowe - o usunięcie skutków naruszenia. Problem pojawia się w przypadku śmierci bliskiej osoby, wówczas bowiem niemożliwe byłoby zastosowanie roszczeń o usunięcie skutków naruszenia środkami niemajątkowymi. W uchwale składu siedmiu sędziów Sądu Najwyższego z dnia 22 października 2019 r. sąd zauważył, że „gdyby [...] potraktować je [więzi rodzinne - K.G.] jako dobro osobiste, chronione prawem bezwzględnym, skutecznym erga omnes (art. 24 k.c.), oznaczałoby to możliwość narzucenia woli innym, czy - patrząc od drugiej strony - wykreowanie powszechnego obowiązku respektowania więzi z innymi osobami”37.

${ }^{34}$ Uchwała Sądu Najwyższego - Izba Cywilna z 22 października 2010 r., III CZP 76/10, Legalis nr 254081.

${ }^{35}$ Wyrok Sądu Najwyższego - Izba Cywilna z dnia 12 lipca 1968 r., I CR 252/68, Legalis nr 13606.

${ }^{36} \mathrm{~W}$ wyroku z dnia 20 października 2015 r., I ACa 1027/15, Legalis nr 1372841, Sąd Apelacyjny we Wrocławiu zwrócił uwagę, że „osoby bliskie mają prawo, aby po śmierci zmarłego pochować i rozpocząć proces żałoby”.

37 Uchwała składu siedmiu sędziów Sądu Najwyższego z dnia 22 października 2019 roku, I NSNZP 2/19, Legalis nr 2236263. 
Znaczenie dla możliwości zakwalifikowania więzi rodzinnej jako dobra osobistego ma także kwestia ich obiektywizacji. Nie wystarczy przyjęcie istnienia abstrakcyjnej więzi emocjonalnej ze zmarłym członkiem rodziny ${ }^{38}$. Samo przekonanie osoby, że więź rodzinna, łącząca ją z członkiem lub członkami rodziny, została naruszona, nie jest wystarczającym argumentem do uznania, że w istocie doszło do naruszenia jej dobra osobistego. W wyroku $z$ dnia 11 marca 1997 r. ${ }^{39}$ Sąd Najwyższy zwrócił uwagę, że oceny naruszenia dobra osobistego należy dokonywać, stosując obiektywizację. Temu celowi ma służyć odwołanie się do uczuć szerszego grona osób, a także do powszechnie przyjętych i akceptowalnych norm postępowania. Pogląd ten koresponduje $\mathrm{z}$ wyrażanymi w doktrynie obawami przed negatywnymi skutkami zbyt szerokiego ujęcia pojęcia więzi rodzinnej i przyznawania jej statusu dobra osobistego. Przede wszystkim może to rodzić wątpliwości powodów, czy w danej sprawie faktycznie naruszono ich dobro osobiste i czy przysługuje im $z$ tego tytułu ochrona. W wyroku z dnia 15 maja 2015 r. ${ }^{40}$ Sąd Apelacyjny w Katowicach rozważył kwestię braku zainteresowania dzieckiem w kontekście naruszenia jego dóbr osobistych. Powódka podniosła, iż na skutek tego, że nie nawiązała więzi $z$ ojcem, który od momentu jej urodzenia nie utrzymywał $z$ nią kontaktu i nie interesował się jej losem, nie mogła przystosować się do życia. Sąd Apelacyjny stwierdził, że chociaż powódka miała prawa pragnąć dorastać w pełnej rodzinie, brak zainteresowania ze strony jej ojca nie naruszył jej dóbr osobistych. W szczególności nie dotyczył dobra w postaci więzi rodzinnych, ponieważ - jak trafnie podniósł Sąd - nigdy nie zostały one nawiązane między nią a jej ojcem. Takie orzeczenie pozwala również

${ }^{38}$ M. Wałachowska, Cywilne prawo - zobowiazania - czyn niedozwolony naruszenie dóbr osobistych członków rodziny $w$ związku ze spowodowaniem śmierci osoby bliskiej. Glosa do wyroku SN z dnia 14 stycznia 2010 r, s. 15.

39 Wyrok Sądu Najwyższego - Izba Cywilna z dnia 11 marca 1997 r., III CKN 33/97, Legalis nr 30799. W analizowanej sprawie powód twierdził, że pracownik domu pogrzebowego naruszył jego dobra osobiste, m.in. jego uczucia i godność, pytając podczas ceremonii pogrzebowej jego matki, w obecności innych żałobników, ile jeszcze potrwa uroczystość, i poruszając tematykę kosztów usługi.

40 Wyrok Sądu Apelacyjnego w Katowicach z dnia 15 maja 2015 r., I ACa 131/15, Legalis nr 1263391. 
wyciągnąć wniosek, że więzi rodzinne nie mają cechy przyrodzoności, skoro w niektórych sytuacjach mogą się w ogóle nie wytworzyć.

\section{Zadośćuczynienie za zerwanie więzi rodzinnej}

Problematykę przyznawania zadośćuczynienia za krzywdę moralną regulował już kodeks zobowiązañ ${ }^{41}$, dopuszczając ją w określonych przypadkach. Możliwość przyznania najbliższym członkom rodziny zadośćuczynienia w przypadku śmierci wskutek naruszenia ciała lub rozstroju zdrowia poszkodowanego Kodeks przewidywał w art. 166. Stosowna suma pieniężna miała stanowić zadośćuczynienie za doznaną przez nich krzywdę moralną. Późniejsze orzecznictwo, a także zmiany legislacyjne odrzuciły możliwość kompensowania najbliższym osobom zmarłego krzywdy doznanej w związku z jego śmiercią. Najwyraźniejszym wyrazem zmian w podejściu do omawianej instytucji była uchwała składu siedmiu sędziów Sądu Najwyższego $z$ dnia 15 grudnia 1951 r. o randze zasady prawnej. Sąd wyraził w niej pogląd, że: „Zasądzenie zadośćuczynienia za krzywdę moralną na rzecz członków rodziny zmarłego należy uznać za sprzeczne $z$ zasadami współżycia społecznego w Państwie Ludowym, chyba że $z$ krzywdą moralną łączy się szkoda materialna nieulegająca zasądzeniu z mocy art. 162 kodeksu zobowiązań” ${ }^{42}$. Stanowisko to zostało utrwalone w kolejnych orzeczeniach Sądu Najwyższego ${ }^{43}$. Artykuł 166 Kodeksu zobowiązań nie znalazł swojego odpowiednika w Kodeksie cywilnym z 1964 r. Późniejsza regulacja przyjmuje, że nie każda szkoda niemajątkowa podlega naprawieniu. Ustawą z dnia 23 sierpnia 1996 r. o zmianie ustawy - Kodeks

${ }^{41}$ Rozporządzenie Prezydenta Rzeczypospolitej z dnia 27 października 1933 r. - Kodeks zobowiązań (Dz.U. z 1933 r. Nr 82, poz. 598).

${ }^{42}$ Uchwała składu siedmiu sędziów Sądu Najwyższego - Izba Cywilna z dnia 15 grudnia 1951 r., C 15/51, Legalis nr 683907.

${ }^{43}$ Orzeczenie Sądu Najwyższego - Izba Cywilna z dnia 13 grudnia 1952 r., C 1208/52, Legalis nr 666540; uchwała Sądu Najwyższego - Izba Cywilna z dnia 29 stycznia 1957 r., I Co 37/56, OSNCK 1958, nr 1, poz. 2. 
cywilny znowelizowano art. 448 k.c. Zmiana umożliwiła zasądzenie zadośćuczynienia w przypadku naruszenia dóbr osobistych. Istotne znaczenie dla ewolucji orzecznictwa w omawianym zakresie ma wyrok Sądu Apelacyjnego w Gdańsku z dnia 23 września 2005 r. ${ }^{44}$, w którym dopuszczono kompensację krzywdy rodziców syna zmarłego na skutek pobicia przez policjanta. Sąd uznał, że więź rodziców $z$ dzieckiem stanowi dobro osobiste i została naruszona bezprawnym, zawinionym działaniem ${ }^{45}$. W wyroku $z$ dnia 14 grudnia 2007 r. ${ }^{46}$ Sąd Apelacyjny w Gdańsku zwrócił natomiast uwagę, że śmierć najbliższego członka rodziny, zawiniona przez osobę trzecią (w omawianym przypadku zmarły był ofiarą wypadku komunikacyjnego), powoduje szkody zdecydowanie bardziej uderzające w sferę psychiki niż w materialne aspekty życia.

Pojawiły się jednak rozbieżności w orzecznictwie, zapadały bowiem także wyroki, w których zadośćuczynienie krzywdy najbliższych członków rodziny osoby zmarłej orzekano na podstawie art. 446 $\S 3$ k.c. Wyroki takie wydawano w sytuacjach, gdy razem $z$ uszczerbkami niemajątkowymi występowały uszczerbki majątkowe ${ }^{47}$. Ustawą z dnia 30 maja 2008 r. o zmianie ustawy - Kodeks cywilny i niektórych innych ustaw do art. 446 k.c. dodano $§ 4$. Zgodnie $z$ jego postanowieniami sąd może przyznać najbliższym członkom rodziny zmarłego odpowiednią sumę tytułem zadośćuczynienia pieniężnego za doznaną krzywdę. Problem rodziła jednak interpretacja tej regulacji, gdyż nie wprowadzono przepisów intertemporalnych, które umożliwiałyby zastosowanie jej w przypadku, gdy śmierć członka rodziny nastąpiła przed dniem 3 sierpnia 2008 r. (czyli przed dniem wejścia przepisu w życie). Do wątpliwości odniósł się Sąd Najwyższy w wyroku z dnia 14 stycznia 2010 r., stanowiąc w tezie: „Spowo-

${ }^{44}$ Wyrok Sądu Apelacyjnego w Gdańsku z dnia 23 września 2005 r., I ACa 554/05, Legalis nr 77703.

${ }^{45} \mathrm{~W}$ aprobującej glosie wskazano, że orzeczenie to odgrywa znaczącą rolę w sferze ochrony dóbr osobistych (M. Wałachowska, Glosa do wyroku s. apel. z dnia 23 września 2005 r., I ACa 554/05, „Przegląd Sądowy” 2007, nr 1, s. 13).

${ }^{46}$ Wyrok Sądu Apelacyjnego w Gdańsku z dnia 14 grudnia 2007 r., I ACa $1137 / 07$, Legalis nr 287203.

${ }^{47}$ Z. Masłowski, w: Kodeks cywilny. Komentarz, t. 2, red. J. Ignatowicz, Warszawa 1972, s. 1119. 
dowanie śmierci osoby bliskiej przed dniem wejścia w życie ustawy z dnia 30 maja 2008 r. o zmianie ustawy - Kodeks cywilny oraz niektórych innych ustaw (Dz.U. z 2008 r., Nr 116, poz. 731) mogło stanowić naruszenie dóbr osobistych najbliższych członków rodziny zmarłego i uzasadniać przyznanie im zadośćuczynienia na podstawie art. 448 k.c." ${ }^{48}$. Takie rozwiązanie niewątpliwie miało na celu ograniczenie dysproporcji sytuacji prawnej najbliższych członków rodziny, którzy doznali krzywdy wskutek śmierci bliskiej osoby przed 3 sierpnia 2008 r. i po tej dacie ${ }^{49}$. Warto jednak zauważyć, że przedtem art. 448 k.c. nie był uznawany w judykaturze za podstawę do zasądzania zadośćuczynienia za krzywdę osób najbliższych związaną ze śmiercią członka rodziny ${ }^{50}$.

Jak wskazano w uzasadnieniu uchwały składu siedmiu sędziów Sądu Najwyższego z dnia 22 października 2019 r., wprowadzenie art. $446 \S 4$ k.c. potwierdziło podział na pośrednio i bezpośrednio poszkodowanych, uzupełniając katalog roszczeń przysługujących bliskim osobom poszkodowanego. Pogląd ten koresponduje $z$ wyrażanym w doktrynie stanowiskiem, że poszkodowanym jest osoba, która doznała szkody w wyniku zachowania nakierowanego na nią (bezpośredni poszkodowany) $^{51}$. Przepis art. $446 \S 4$ k.c. nie wymaga od powoda wykazania, że jego dobro osobiste zostało naruszone. Tym samym, jak wskazuje Sąd Najwyższy w wymienionej wyżej

48 Wyrok Sądu Najwyższego z 14 stycznia 2010 r., IV CSK 307/09, Legalis nr 254072.

${ }^{49}$ M. Wałachowska w glosie do omawianego wyroku zwraca jednak uwagę, że w przypadku, gdy naruszenie dobra nastąpiło przed 3 sierpnia 2008 r., a powodowie na skutek śmierci członka rodziny doznali rozstroju zdrowia, zastosowanie ma art. 445 § 1 k.c., nie art. 448 k.c. (M. Wałachowska, Cywilne prawo - zobowiazania - czyn niedozwolony - naruszenie dóbr osobistych członków rodziny $w$ związku ze spowodowaniem śmierci osoby bliskiej. Glosa do wyroku SN z dnia 14 stycznia 2010 r., s. 15).

${ }^{50}$ W wyroku z dnia 6 lutego 2008 r., II CSK 459/07 Sąd Najwyższy jako podstawę zadośćuczynienia powołał art. 446 § 3. Wyraźnie oddzielił naruszenie sfery psychicznej spowodowane śmiercią członka najbliższej rodziny od naruszenia dobra osobistego.

${ }^{51}$ M. Wałachowska, Roszczenie o zadośćuczynienie pieniężne za zerwanie więzi rodzinnych $w$ razie doznania przez osobę bliska poważnego uszczerbku na zdrowiu, „Przegląd Sądowy” 2017, nr 9, s. 11-25, M. Kaliński, op.cit., s. 10. 
uchwale, nie stanowi on argumentu na rzecz przyznawania więzi rodzinnej statusu dobra osobistego. Jest natomiast wyraźną podstawą do ochrony interesów niemajątkowych o innym charakterze, przesłanką jego zastosowania jest bowiem doznanie krzywdy przez uprawnionego, a nie naruszenie jego dobra osobistego. Ma to na celu kompleksową regulację roszczeń przysługujących najbliższym członkom rodziny, bez potrzeby kreowania dobra osobistego w postaci więzi rodzinnej i rozszerzania jego interpretacji ${ }^{52}$. Orzecznictwo przed omawianą uchwałą szło jednak w kierunku uznawania więzi rodzinnej za dobro osobiste, wskazując, że niemajątkowe interesy osób bliskich zmarłemu bezpośrednio doznają uszczerbku wskutek jego śmierci. W tezie wyroku z dnia 20 sierpnia 2015 r. Sąd Najwyższy wskazał, że „powód żądający tego świadczenia na tej podstawie [zadośćuczynienia za śmierć bliskiej osoby na skutek naruszenia dobra osobistego] jest bezpośrednio poszkodowany [...]"53. Musi on wykazać jednak, że oprócz formalnych więzi rodzinnych łączyły go ze zmarłym także relacje emocjonalne.

Kontrowersje budzi przede wszystkim przyznawanie zadośćuczynienia na podstawie art. 448 k.c. w przypadku, gdy członek rodziny nadal żyje, jednak znajduje się w wegetatywnym, ciężkim stanie. Teza wyroku Sądu Apelacyjnego w Warszawie z dnia 18 stycznia 2016 r. wprost wskazuje, że: „Rodzice upośledzonego dziecka, które na skutek winy lekarzy przy porodzie doznało ciężkiego uszkodzenia ciała o skutkach trwałych i nieodwracalnych, mogą żądać zadośćuczynienia za wyrządzoną im krzywdę. Naruszone zostało bowiem ich prawo do niezakłóconego życia w pełnej rodzinie, mimo że więzy rodzinne faktycznie nie zostały zerwane; pozbawieni jednak zostali realnej możliwości budowania, pielęgnowania i kształtowania prawidłowych relacji rodzin-

52 Sąd Najwyższy podniósł, że art. 448 k.c. miał za zadanie ujednolicić sytuację osób, których najbliżsi członkowie rodziny zmarli przed 3 sierpnia 2008 r., i tych, których bliscy odeszli po tej dacie. Wobec orzeczeń, które sprecyzowały, że art. $446 \S 4$ k.c. może być stosowany, gdy śmierć nastąpiła przed 3 sierpnia 2008 r. m.in. wyrok Sądu Najwyższego z 14 stycznia 2010 r., IV CSK 307/09), Sąd Najwyższy uznał, że powoływanie art. 488 k.c. nie jest już dłużej konieczne.

${ }^{53}$ Wyrok Sądu Najwyższego - Izba Cywilna z dnia 20 sierpnia 2015 r., II CSK 595/14, Legalis nr 1337753. 
nych" ${ }^{4}$. W tezie wyroku z dnia 6 lipca 2018 r. Sąd Najwyższy wyraźnie uznał możliwość zrównania śmierci i ciężkiego uszczerbku na zdrowiu członka rodziny, stanowiąc: „Przyznanie osobom najbliższym poszkodowanego zadośćuczynienia na podstawie art. 24 i 448 k.c. jest możliwe tylko wtedy, gdy stan zdrowia poszkodowanego czynem niedozwolonym można porównać ze śmiercią poszkodowanego" ${ }^{5}$. W doktrynie zwrócono jednak uwagę, że nie jest słusznym podejściem „wartościowanie” więzi między członkami rodziny ${ }^{56}$.

\section{Podsumowanie}

Wobec funkcjonujących w obrocie prawnym uchwał Sądu Najwyższego, odmiennie ujmujących więzi rodzinne w kontekście usytuowania ich wśród dóbr osobistych w rozumieniu art. 23 k.c., ich status jest niedookreślony. Powoduje to stan niepewności prawnej co do roszczeń przysługujących członkom rodziny poszkodowanego, który na skutek niedozwolonego czynu doznał ciężkiego i trwałego rozstroju zdrowia. Problematyka ta powinna stać się przedmiotem uchwały izb połączonych Sądu Najwyższego. Sprzeczne uchwały w składzie siedmiu sędziów Sądu Najwyższego wydały bowiem dwie izby - Izba Cywilna oraz Izba Kontroli Nadzwyczajnej i Spraw Publicznych. Warto, aby wzięto pod uwagę podniesione w uchwale z 2 października 2019 r. argumenty odmawiające więzi rodzinnej statusu dobra osobistego, które stanowią klamrę spinającą wątpliwości, podzielane także przez przedstawicieli doktryny, co do zasadności wcześniejszej kwalifikacji więzi rodzinnej. Trudno nie podzielać wyrażonych przez Sąd Najwyższy zastrzeżeń, czy wobec niejednoznaczności pojęcia więzi rodzinnej powoływanie się na nią nie będzie prowadziło do nadinterpretacji i nieuzasadnionego nadużywania instytucji dobra osobistego. Jak podkreślono w uza-

${ }^{54}$ Wyrok Sądu Apelacyjnego w Warszawie z dnia 18 stycznia 2016 r., VI ACA 1405/14, Legalis nr 1587431.

${ }^{55}$ Wyrok Sądu Najwyższego - Izba Cywilna z dnia 6 lipca 2018 r., II CSK 233/17, Legalis nr 1804716.

${ }^{56}$ T. Grzeszak, op.cit., s. 38; L. Bosek, op.cit., s. 11. 
sadnieniu uchwały Sądu Najwyższego z dnia 19 listopada 2010 r. ${ }^{57}$, „ochrona dóbr osobistych ma charakter wyjątkowy, w związku z czym sięganie do jej mechanizmów powinno następować z odpowiednią ostrożnością i powściągliwością, bez tendencji do sztucznego poszerzania katalogu tych dóbr”.

\section{STRESZCZENIE}

Więzi rodzinne a problematyka dóbr osobistych

Celem artykułu jest analiza statusu więzi rodzinnych jako dobra osobistego w oparciu o dotychczasowe orzecznictwo i poglądy doktryny. Rozważania koncentrują się na poszukiwaniu odpowiedzi na pytanie o zasadność przyznania im statusu dobra osobistego w rozumieniu art. 23 k.c. Autorka zwraca uwagę na niepewność prawną związaną $z$ funkcjonującymi w obrocie prawnym uchwałami Sądu Najwyższego, prezentującymi odmienne stanowiska co do analizowanego zagadnienia, i konieczność jej rozstrzygnięcia.

Słowa kluczowe: więzi rodzinne; dobra osobiste; szkoda niemajątkowa; ochrona dóbr osobistych

\section{SUMMARY}

Family bonds and personal rights

The aim of this article is to analyze family bonds considered as a personal right on the basis of legal academics and commentators, as well as judicial decisions. Focus has been placed on questioning legitimacy of considering family bonds as a personal right as referred to in art. 23 of the Polish Civil Code. The author highlights the legal problem arisen from resolutions of the Polish Supreme Court which present two inconsistent understandings of the analyzed issue and points out the necessity of its resolving.

Keywords: family bonds; personal rights; non-financial damage; protection of personal rights

57 Uchwała Sądu Najwyższego - Izba Cywilna z dnia 19 listopada 2010 r., III CZP 79/10, Legalis nr 260723. 


\section{BIBLIOGRAFIA}

Bosek L., W sprawie kwalifikacji więzi rodzinnej jako dobra osobistego (uwagi krytyczne na tle aktualnego orzecznictwa Sądu Najwyższego), „Forum Prawnicze” 2015, nr 3.

Grzeszak T., Dobro osobiste jako dobro zindywidualizowane, „Przegląd Sądowy" 2018, $\mathrm{nr} 4$.

Grzybowski S., Ochrona dóbr osobistych, Warszawa 1957.

Grzybowski S. (red.), System prawa cywilnego, t. 1. Część ogólna, Wrocław-Warszawa-Kraków-Gdańsk-Łódź 1985.

Kaliński M., Ograniczenie indemnizacji do podmiotów bezpośrednio poszkodowanych $-w$ zwiazku $z$ nowelizacja art. 446 Kodeksu cywilnego, „Przegląd Sądowy” 2004, nr 3.

Księżak P., w: Kodeks cywilny. Część ogólna. Komentarz, red. M. Pyziak-Szafnicka, P. Księżak, Warszawa 2014.

Lackoroński B., Cywilne prawo - zobowiąania - dobra osobiste - czyn niedozwolony - zadośćuczynienie pieniężne za doznana krzywdę $w$ zwiazku ze śmiercia najbliższego członka rodziny na skutek deliktu, który miał miejsce przed dniem 3 sierpnia $2008 \mathrm{r}$. Glosa do uchwaty $\mathrm{SN}$ z dnia 22 października 2010 r., III CZP 76/10, „Orzecznictwo Sądów Polskich” $2011, \mathrm{nr} 9$.

Masłowski Z., w: Kodeks cywilny. Komentarz, t. 2, red. J. Ignatowicz, Warszawa 1972.

Sobolewski P., w: Kodeks cywilny. Komentarz, red. K. Osajda, Warszawa 2017.

Wałachowska M., Cywilne prawo - zobowiązania - czyn niedozwolony naruszenie dóbr osobistych członków rodziny $w$ związku ze spowodowaniem śmierci osoby bliskiej. Glosa do wyroku SN z 14 stycznia 2010 r., IV CSK 307/09, „Orzecznictwo Sądów Polskich” 2011, nr 2.

Wałachowska M., Cywilne prawo - zobowiazania - dobra osobiste - czyn niedozwolony - zadośćuczynienie pieniężne za doznana krzywdę $w$ zwiazku ze śmiercią najbliższego członka rodziny na skutek deliktu, który miał miejsce przed dniem 3 sierpnia 2008 r. Glosa do uchwaty SN z dnia 22 października 2010 r., III CZP 76/10, „Orzecznictwo Sądów Polskich” 2011, nr 9.

Wałachowska M., Glosa do wyroku s. apel. w Gdańsku z dnia 23 września 2005 r., I ACa 554/05, „Przegląd Sądowy” 2007, nr 1.

Wałachowska M., Roszczenie o zadośćuczynienie pieniężne za zerwanie więzi rodzinnych $w$ razie doznania przez osobę bliska poważnego uszczerbku na zdrowiu, „Przegląd Sądowy” 2017, nr 9. 